\title{
An Analysis on the Web Portals of the Municipalities Comprising the Regional Development Bureau of Joinville (SC), Based on a Multicriteria Decisionmaking Model
}

\author{
Enéias Alexandre Staroscky ${ }^{1}$, Maurício Vasconcellos Leão Lyrio ${ }^{1,2}$, Rogério João Lunkes ${ }^{1}$, Belchior Pedro Cole ${ }^{1}$ \\ \& Gissele Souza de Franceschi Nunes ${ }^{1}$ \\ ${ }^{1}$ Santa Catarina Federal University, Florianópolis, Brazil \\ ${ }^{2}$ Capes Foundation, Ministry of Education of Brazil, Brasília - DF 70.040-020, Brazil \\ Correspondence: Maurício Vasconcellos Leão Lyrio. Secretaria de Estado da Administração, Consultoria de \\ Planejamento - CPLAN. Centro Administrativo, Rod. SC 401 Km 05, n 4.600, Saco Grande II, 88032-000 - \\ Florianópolis, SC - Brasil. E-mail: mauriciovll@gmail.com
}

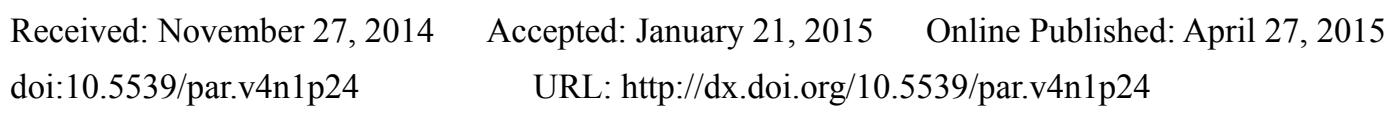

\begin{abstract}
The present work seeks to evaluate the level of transparency demonstrated by the online portals of city governments that make up the Regional Development Bureau -RDB- of the municipality of Joinville, in the State of Santa Catarina, Brazil, employing a mixed quali-quantitative approach to the research problem. The study being of exploratory and descriptive character, the model proposed by Nunes (2013) was used, which was developed by way of an application of the Multicriteria Decision Aid - Constructivist (MCDA-C) methodology. The results showed, in general, a low level of transparency in the web portals of the municipalities analyzed, with an average of two points. In synthesis, the comprehensive evaluation of each municipality indicated that $50 \%$ of them do not disclose that which is required by Brazilian legislation. The positive standout among the sample is the City of Joinville, which showed the highest level of transparency with 29 points; conversely, the City of Balneário Barra do Sul stood out in a negative light, with the lowest score, at -12 points. The application of the Nunes (2003) model as well as comparisons with the results of previous studies made evident several contrasts in the level of transparency of municipal web portals from different regions of the state, while also demonstrating the potential of the same for continued evaluation of the level of transparency of the web portals and its capacity for suggesting steps for enhancing them.
\end{abstract}

Keywords: public sector, transparency, municipal web portals, MCDA-C methodology

\section{Introduction}

In 2013, Brazil was host to a series of democratic protests. Masses of citizens took to the streets demanding better conditions of health, education, safety, and other topics of importance to the Brazilian nation. Among the latter were calls for improved usage of public funds, greater transparency and an end to corruption, which erodes the Brazilian public sector, and is considered an endemic problem within the public sector on a global level (Riley, 1988; Olowu, 1999; Zipparo, 1999; Zafarullah; Siddiquee, 2001; Davis, 2004; Pillay, 2004).

Transparency can be considered the soul of the democratic system, with a greater degree of it, as well as openness, resulting in a better ability, on part of the public, to be aware of the actions of elected officials (Kierkegaard, 2009). In the case of Brazil, the information gap that exists as a result of the lack of transparency is not an isolated problem, but rather, it has come to form part of the country's culture. These circumstances present, a cultural shift is necessary, one in which the norm will change from "the duty to inform" to "the desire to inform."

As such, transparency in public administration becomes essential to society's knowledge of activities carried out by public entities; however, beyond the mere publication of these activities, it is fundamental that the public be made aware of funds raised and expensed, given that these are collected from taxpayers. This knowledge of how tax revenues and public expenses are managed is a central part of any democracy, standing as a principle of efficient and effective public administration. The tool used by the State for the broadcast of information regarding public accounts are online web portals. In light of these considerations, the following research question 
emerges: "what is the level of transparency of the web portals of the municipalities making up the Regional Development Bureau of Joinville, SC, in accordance with the related requirements stated in Brazilian legislation?"

Beginning in 2003, according to Lyrio (2008), the Government of the State of Santa Catarina began a process of administrative restructuring in which the governmental structure was decentralized, allowing for greater proximity in terms of response to the needs of its citizens. Toward this end, 29 Regional Development Bureaus (henceforth, RDB) were created, with seven more added by the end of the restructuring process in 2007, yielding a total of 36 RDBs. These bureaus were created with the objective of bringing state government closer to municipal managers, given the need for supervision, coordination, guidance and control in of the programs, projects, and activities in accordance with their respective areas of expertise, joint efforts with Sector Bureaus.

The general objective of this work is to verify the level of transparency of the municipal web portals maintained by the municipalities making up the Joinville RDB, as per the standards set in related Brazilian legislation. The selection of this particular RDB is based on this region's importance to the economy and culture of Santa Catarina, given that the region contains more than 16,000 national and international companies, which together generate $15.5 \%$ of the GDP of the state (FIESC, 2013); its primary municipality - Joinville - is the most populous of the state, and it also hosts the Joinville Dance Festival and is home to the School of Bolshoi Theatre of Brazil, among other responsibilities. To achieve its general objective, the study established the following specific objectives: (I) a verification of the adherence to related Brazilian legislation displayed in information published in the web portals of the city halls making up the RDB of Joinville-SC; (II) an analysis of the level of transparency of each of the region's web portals, by way of an application of the model proposed by Nunes (2013); and, (III) a comparison of the results obtained with those of a previous study carried out by Staroscky et al. (2013) concerning the municipalities making up the RDB of Chapecó.

Following this introduction, in its second section - theoretical framework - this study presents a discussion on public administration and its relationship to transparency, concepts of transparency, its presentation in Brazilian legislation, as well as previous studies in this field. Section III - methodology - outlines the methodological framework of the article, the intervention instrument employed and the procedures followed during data collection and analysis. Section IV presents the results obtained, with a comparison to those of previous studies. Finally, Section V contains the final considerations of the study.

\section{Theoretical Framework}

\subsection{Public Administration and Its Relationship to Transparency}

Following the Industrial Revolution, when the modern State took form, the need for the public to be informed as to the government's decisions did as well, with its expenses and investments chief among these. As time passed, this need grew greater and greater. Though he highlights the growth of corruption in the twentieth and twenty-first centuries, Slomski (2009) mentions that it had, in fact, already come into existence in previous centuries, but its scope was unknown due to a communication problem; namely, a gap between the information generated and that presented to citizens. In other words, the author (Slomski, 2009) argues that, in recent years, there is greater mention of corruption in the media resulting from a shrinking information gap.

In truth, reforms taking place in public administration contributed to the reduction of that information gap. Chart 1 summarizes the characteristics of each of the conceptual frameworks emerging from public administration reforms. 


\begin{tabular}{cccc}
\hline Characteristic & Bureaucracy & NPM & Public Governance \\
\hline $\begin{array}{c}\text { Role of the System } \\
\text { System's relationship to the } \\
\text { environment }\end{array}$ & $\begin{array}{c}\text { Homeostasis } \\
\text { Closed }\end{array}$ & $\begin{array}{c}\text { Homeostasis } \\
\text { Open }\end{array}$ & Homeostasis \\
$\begin{array}{c}\text { Open } \\
\text { istinction between politics and } \\
\text { administration }\end{array}$ & Separate & Working together, at & Obscured \\
Emphasized administrative & political behest & distinction \\
functions & Control and & Control and planning & Control and \\
Administrative discretion & Low & High & coordination \\
Citizens are viewed as: & Users & Clients & N/A \\
\hline
\end{tabular}

Chart 1. Basic characteristics of the conceptual models emerging from public administration reforms

Source. Adapted from Secchi (2009, pg. 364)

In Chart 1, it is evident that, in respects to the role of the governmental system, each of the models, whether it be the bureaucratic, the New Public Management - NPM, or the Public Governance model, display properties of homeostasis which is to say, they seek to regulate their internal environment in hopes of maintaining stability by way of interrelated control and regulation mechanisms.

In relation to the external environment, the bureaucratic model tends to be closed off, based on its well-defined hierarchical relationships, which in turn emphasize a mechanical interpretation of the organization, with a hierarchical, departmentalized, and substantially-endowed-with-autonomy functional structure, in management terms (Bergue, 2011). At the same time, the model proposed by NPM tends toward a greater focus on results, as opposed to means, with an emphasis on greater efficiency and effectiveness on part of the State, displaying traits evident in the private sector (Secchi, 2009). Finally, the Public Governance model seeks to bind the State, economy, and society together through a political-developmental dialogue, with the goal of guiding the development of public policy (Kissler; Heidemann, 2006).

There exists a distinction between politics and administration in the bureaucratic model and it is noticeably stressed. Along with this, this distinction also exists in the NPM model, but it becomes a joint task between two separate entities - politician and administrator - with the former holding greater authority. In the case of Public Governance, this distinction is obscured by way of an attempt to form a consensus between various interests, in which a dialogue between those two entities and society on the whole is carried out, contributing to the greater objective of the establishment of legitimate public policies.

In terms of discretion, the bureaucratic model displays a low degree of the same, which is to say, it is capable of divorcing itself from public interests and, stemming from the emphasis placed on controlling its operations, it often ends up falling short on its attention to the needs of society. The NPM model, alternately, displays a higher level of discretion, and as such it allows for a greater liberty, on part of the public administrator, to act in accords with what is deemed best in a given situation. In the case of Public Governance, this issue is of lesser importance as this model seeks a greater consensus among the interrelated parts of the development of public policy and service, placing greater emphasis on the role of society in those developments.

Finally, it can be stated that within the realm of bureaucratic public administration, the citizen is seen as a user of the system; within the NPM model, as a client in need of attention; and, in the Public Governance model, as a partner for the establishment of public policies. In this light, along the path towards the adoption of a Public Governance model, and keeping the role of the citizen in mind, greater transparency in the provision of information becomes necessary so that society is able to support the establishment of policies, as well as comprehend the veritable scope of the objectives set by the State, all of which opens a space for a discussion on public sector transparency.

\subsection{Transparency}

Upon consideration of governance in public administration, Slomski (2009, pg. 17) asserts that it is necessary to have transparency, equity, accountability and corporate responsibility as principles. From this, transparency is one of the elements necessary for good public governance to be achieved.

Transparency, in the sense that is defended in this study, is related to publicity, to what is public, in regards to 
which Thompson (1998 apud Tavares; Pereira, 2011, pg. 4) states that

'public' means 'open' or 'accessible to the public. 'Public, in this sense, is that which is visible or perceptible, what is done in from of spectators, what is open so that all or many can see or hear. Private is, on the contrary, that which is hidden from the view of others, what is said or done in privacy or secret, or within a circle of people. In this sense, the dichotomy has to do with publicity versus privacy, with open-ness versus secrecy, with visibility versus invisibility.

For transparency to be effected, it is essential that there be a reduction -or better, if possible, elimination- of informational asymmetry. Slomski (2009) posits that the State communicates, but the public does not comprehend, and to avoid this and also increase transparency, the author states instruments that shrink this information gap exist, for example: the statement of economic income, comprehensive activities report and the social balance sheet, which do not limit themselves to strictly economic-financial performance, but rather incorporate intangible factors that facilitate transparency, and the greater understanding of activities carried out by public administrators, including those outside of those required of them.

\subsubsection{Public Transparency in Brazilian Legislation}

The Constitution Brazil of 1988, in article V, subsection XXXIII states that:

all people have a right to receive information, regarding personal or public interest, from public institutions, which will be issued in accordance with the law, as per the duties stipulated, excepting those whose secrecy is indispensable to the safety of society and that of the State (note: translation by authors)

Building off the Constitution of Brazil of 1988, recent legislation also contributes to the process of reducing informational asymmetry. The first contributor to this process was the "Complementary Law (Lei Complementar $\{\mathrm{LC}\}) \mathrm{n}^{\circ} 101$ " of 2000 , which later became known as the "Fiscal Responsibility Law (Lei de Responsabilidade Fiscal $\{\mathrm{LRF}\})$ )". The LRF, besides putting forth principles of responsible management of public finances, also included rules regarding transparency, control, and inspection.

In 2009, the LC 131 adjusted certain aspects of the LRF, calling for greater transparency in public administration, for the purposes of which, detailed information, using electronic mediums for public access, must be disclosed in real time for widespread understanding of financial and budgeting activities of public institutions.

To standardize the quality of the various public information systems, the President of the Republic of Brazil issued "Decree (Decreto) $n^{\circ} 7,185$ ", with the objective of setting minimum quality standards for integrated financial administration and control systems, uniform across each state of the Federation.

Continuing this process of enhancing transparency and in step with the recent international tendency toward the same, on November 18th, 2011, "Law $\mathrm{N}^{\circ} 12,527$ " was passed, which came to be known as the Access to Information Law (Lei de Acesso à Informação $\{\mathrm{LAI}\}$ ), coming into effect halfway through 2012. By way of the LAI, regulations concerning access to information regarding the activities of public administration, whether pertaining to the executive, legislative, or judicial branch, were instated.

The LAI served to shift existing paradigms, as affirmed by the Controller General of the Union (Controladoria General da União \{CGU\}) (2011), by establishing the principle that secrecy be the exception and open access to information the norm. In light of this, the purpose of this study is to verify the degree of adherence to this legislation exhibited by the web portals of the examined municipalities. Following, previous studies that contributed to the execution and improvement of the present work are analyzed.

\subsubsection{Previous Related Studies}

Nunes (2013) proposed a model for analyzing web portals, whether they be municipal, state, or pertaining to other institutions. His analysis was carried out in concerns to municipalities located in Southern Brazil with more than 50,000 inhabitants. The average score shown by the municipalities in the sample was 24 points, falling between neutral and good. The highest-scoring municipality was Porto Alegre (RS), while the worst was Alborado, which is also located in the Rio Grande do Sul state. One of the municipalities considered in the present study, Joinville, placed 32nd in the ranking of the southern region compiled by the author.

Staroscky et al. (2013) analyzed the municipalities of the Chapecó RDB, based off a test of the Nunes (2013) model. The results obtained showed a low level of transparency among the municipalities analyzed, which displayed an average of negative 15 points, on a scale ranging from -50 to 150 points. Of the sample, the standout was the municipality of Nova Erechim, which held the highest overall score at 15, while the lowest 
scorer was Águas Frias, with -43 points.

The authors of Pires et al. (2013) completed a study with goals similar to those of the present work. Their research consisted of an analysis of the web portals of the Santa Maria and Novo Hamburgo municipalities, both located in the Rio Grande do Sul state. The criteria set forth in Lei $n^{\circ} 12.527 / 2011$, it being the Brazilian Law of Access to Information, were taken into consideration; those that were met completely received a score of two, while those that were partially met received one, and those that were not met at all, zero points. With this standard in place, the authors observed that Santa Maria displays many areas for improvement, as it tallied only 23 of the maximum 40 points. Along with this, the Novo Hamburgo web portal was shown to be the best in practice for its score of 35 points.

Over the course of the current research, several other studies on public sector transparency at the international level were reflected (Bordignon; Minelli, 2001; MCivor; Mchugh; Cadden, 2002; Rossi; Murillo Fort; Puente-Karolys, 2002). Regarding resource-allocation transparency, Bordignon and Minelli (2001) offered a political-economic explanation of the rules for public sector resources allocation and distribution, arguing that different rules might induce different types of behavior, as well as present different information content in related reports. Rossi, Murillo-Fort and Puente-Karolys (2002), in turn, argued that corruption may be associated with a lack of public sector transparency, primarily in public acquisitions negotiations, discussing the topic within the context of public hospitals in Buenos Aires.

McIvor, McHugh, and Cadden (2002) sought to indicate how internet technology is capable of facilitating the reach of transparency in public sector organizations, arguing that this type of technology will have an impact on how these public sector organizations interact with the external environment, as well as with the users of their services. The present work continues this discussion, seeking to analyze the level of transparency of the web portals of the municipalities making up the Joinville RDB, going on to contribute to research on public sector transparency.

In the scope of legislative power, Hillebrandt, Curtin and Meijer (2014) discussed the Council of Ministers's policy changes on US between 1992 and 2006, from an historical institutional analysis. Ríos, Bastida and Benito (2014) sought to evaluate the role that the legislative budget oversight plays in strengthening the budget transparency. Finally, with regard to the judiciary power, Grimmelikhuijsen and Klijn (2015) conducted a field experiment in which discuss the relationship between public trust and judicial transparency arguing that it has effects on trust.

\section{Method}

Continuing with the execution of the study, the research methodology was divided into three parts, which were: (i) the methodological structure; (ii) the intervention instrument; and (iii) data collection and analysis procedures.

\subsection{Methodological Structure}

In terms of its approach, this study is characterized as mixed, quali-quantitative research. Qualitative, in regards to the investigations made into web portals available on the internet, with the goal of verifying the degree of adherence to Brazilian legislation displayed by the same in the information presented by each. For its use of the model proposed by Nunes (2013) for the measurement of the level of transparency, this study is also characterized as quantitative research. In relation to its objectives, it is an exploratory and descriptive study. Following the logic applied in Gil (2010), the present work falls under the category of exploratory research as a result of its use of the Nunes (2013) model for a better understanding of the level of transparency of municipal web portals. It is also a descriptive study, given that, as stated by the author, it has as its objective the description of a determined population and an analysis of the relationships between certain variables present within.

\subsection{Intervention Instrument}

The evaluation model employed here to quantify the level of transparency of the municipal web portals was proposed by Nunes (2013), having been previously tested in Staroscky et al. (2013). This model was developed with its base in the Multicriteria Decision Aid - Constructivist (MCDA-C) methodology (Ensslin; Montibeller-Neto; Noronha, 2001). Roy and Vanderpooten (1996) affirmed that the MCDA methodology emerged from operations research, beginning in the 1970s, and was later divided into two multicriteria schools. The American school, given its respective point of view, utilizes the Multicriteria Decision-Making - MCDM approach; the European, the Multicriteria Decision Aid - MCDA.

According to Roy (1993 and 1994), what differentiates the American and European-school methodologies from one another is the first's interpretation of the search for an optimal solution to the research problem, in the case of which those involved have a full knowledge of that for what they are looking; the second, in contrast, seeks to 
organize the decision-making process based off the convictions of those involved, arriving at an adequate solution as per the specific context.

Lyrio (2008) states that, to reach its objective, the MCDA-C methodology makes use of decision-aid activities that comprise three phases: (i) the structuring phase, (ii) the evaluation phase, and (iii) the recommendations preparation phase.

Lyrio et al. (2008), in turn, argue that the utilization of the MCDA-C methodology for the construction of evaluation models stands out for its ability to allow for the proposal of recommendations for improvements to evaluation models, based off the level of performance of each criterion. As an example, Figure 1 demonstrates that it is possible to note the current level of performance in regards to each analysis criterion and, upon analysis of the criteria that fail to meet the desired level of performance (GOOD), propose recommendations so that the deficiencies in the web portals can be resolved, proving relevant to the research methodology and, along these lines, justifying its selection as intervention instrument.

\subsection{Data Collection and Analysis Procedures}

It bears mentioning that the model proposed by Nunes (2013) takes legislation dealing with transparency in the disclosure of public-sector institutions into consideration, specifically: Complementary Law (Lei Complementar) $\mathrm{n}^{\circ} .101$, passed in 2000 (LRF), Complementary Law (Lei Complementar) $n^{\circ}$. 131/2009, Decree (Decreto) 7.185/2010 and the LAI, or, Law n ${ }^{\circ} 12.527 / 2011$.

This model is composed of 36 criteria similar to those presented in Chart 2, with each one possessing five levels of impact. At the lowest level (L1), the score received is 50 negative points, which is penalty for not reaching a neutral score (L2) of zero, which means that the municipal web portal discloses only that information required by related legislation. The following three levels L3, L4, and L5 receive 50, 100, and 150 points, respectively. It is at these levels that the quality of information disclosed is measured; for the purposes of analysis, L4 was defined as "good", and above that (L5), the quality of the information is deemed excellent.

\begin{tabular}{|c|c|c|c|}
\hline $\begin{array}{c}\text { Impact } \\
\text { Level }\end{array}$ & $\begin{array}{c}\text { Reference } \\
\text { Level }\end{array}$ & Ordinal Scale & $\begin{array}{l}\text { Cardinal } \\
\text { Scale }\end{array}$ \\
\hline L5 & & $\begin{array}{l}\text { Disclose, in a complete and detailed fashion, the projected cost(s) of the } \\
\text { activity, its corresponding work order number, allow for searches by } \\
\text { agency, budgetary classification, length, creditor, project, and project } \\
\text { summary in clear and concise wording: itemized for final allocation, } \\
\text { possibility of identifying the values relative to projected, processed, and } \\
\text { non-processed costs, as well as those paid and awaiting payment. }\end{array}$ & 150 \\
\hline L4 & GOOD & $\begin{array}{l}\text { Disclose, in a complete and detailed fashion, the projected cost(s) of the } \\
\text { activity, its corresponding work order number, and allow for searching by } \\
\text { agency, budgetary classification, length, creditor, project, and project } \\
\text { summary in clear and concise wording: itemized for final allocation }\end{array}$ & 100 \\
\hline L3 & & $\begin{array}{l}\text { Disclose, in a complete and detailed fashion, the projected cost(s) of the } \\
\text { activity, its corresponding work order number, receipt number, and allow } \\
\text { for searching by agency, budgetary classification, length and lender. }\end{array}$ & 50 \\
\hline L2 & NEUTRAL & $\begin{array}{l}\text { Disclose, in a complete and detailed fashion, the projected cost(s) of the } \\
\text { activity, its corresponding work order, if it is the case. }\end{array}$ & 0 \\
\hline L1 & & $\begin{array}{l}\text { Projected cost(s) of activity or corresponding work order number missing, } \\
\text { if it is the case. }\end{array}$ & -50 \\
\hline \multicolumn{4}{|c|}{$\begin{array}{l}\text { Scale Criteria: Corroborate the disclosure of the projected disbursement, as according to Article } 7 \text { of Federal } \\
\text { Decree } n^{\circ} 7.185 \text {, passed May } 27^{\text {th }}, 2010 \text {, in conjunction with Article } 48 \text {-a, I of the Fiscal Responsibility Law and } \\
\text { Article } 8 \text {, III of Law } n^{\circ} 12.527 \text {, passed November } 18^{\text {th }}, 2011 \text {. }\end{array}$} \\
\hline
\end{tabular}

Chart 2. Descriptions of activities reporting evaluation

Source: Adapted from Nunes (2013, pgs. 140-141). 
As previously stated, municipalities that are under the supervision and jurisdiction of the Joinville RDB were analyzed in this study, and as such the research sample is composed of eight municipalities: Araquari (ARQ), Balneário Barra do Sul (BBS), Barra Velha (BRV), Garuva (GRV), Itapoá (ITP), Joinville (JOI), São Francisco do Sul (SFS) e São João do Itaperiú (SJI). Table 1 presents an overview of the municipalities analyzed that make up the Joinville RDB, showing, for the purpose of comparison, these statistics: population, gross domestic product (GDP), GDP per capita, and the municipal human development index (MHDI) score.

Table 1. Overview of municipalities analyzed

\begin{tabular}{lllll}
\hline MUNICIPALITY & $\mathbf{2 0 1 0}$ POPULATION & $\begin{array}{l}\text { GDP 2011 } \\
(\mathbf{R} \$ \mathbf{1 , 0 0 0})\end{array}$ & $\begin{array}{l}\text { GDP 2011 } \\
\text { per capita }\end{array}$ & $\begin{array}{l}\text { MHDI } \\
\mathbf{2 0 1 0}\end{array}$ \\
\hline ARAQUARI & 24,810 & 595,107 & 23,987 & 0.703 \\
BALNEÁRIO BARRA DO SUL8,430 & 107,127 & 12,708 & 0.716 \\
BARRA VELHA & 22,386 & 429,245 & 19,175 & 0.738 \\
GARUVA & 14,761 & 443,011 & 30,012 & 0.725 \\
ITAPOÁ & 14,763 & 197,672 & 13,390 & 0.761 \\
JOINVILLE & 515,288 & $18,797,540$ & 36,480 & 0.809 \\
SÃO FRANCISCO DO SUL & 42,520 & $4,348,280$ & 102,264 & 0.762 \\
SÃO JOÃO DO ITAPERIÚ & 3,435 & 75,787 & 22,063 & 0.738 \\
\hline
\end{tabular}

Source. Adapted from IBGE (2014).

An analysis of each criteria, one at a time, municipality by municipality, was carried out between September 13, 2013 and February 2, 2014. In his study, Nunes (2013) analyzed all of the municipalities of the southern region of the country with 50,000 or more inhabitants, showing that, within the Joinville RDB, only the city of Joinville meets that requirement. Given these circumstances, in the case of the Joinville municipality, for the development of analyses, data already gathered by Nunes (2013, pg. 101) were utilized. With the objective of documenting the municipalities' displayed transparency levels, the print screen function was employed, including the date and time, by way of which the criteria pertaining to each municipal web portal were verified. The systems used by each of the municipal web portals were also surveyed. Following, the three systems employed (represented as ST1, ST2, ST2a and ST3) are indicated in Table 2. ST2 and ST2a differ only for the layout of the information disclosed by each, given that the developer of the systems is a single company.

\section{Presentation and Analysis of Results}

In this section of the study, the presentation and analysis of the results will be carried out, so that they can later be compared with those of Staroscky et al. (2013).

Figure 1 presents the hierarchical value structure, the criteria used and the performance evaluation of the Joinville RDB municipal web portals. The criteria are divided into three areas of concern: (1) information content, (2) usability, and (3) data availability, each of which are weighted at $70 \%, 15 \%$, and $15 \%$, respectively, in terms of the overall evaluation of the municipality.

The overview of the Joinville municipality's performance, displayed in Figure 1, shows that the municipality scored a good rating in half of the criteria falling under the theme of information content. However, its performance placed below expectations in subsequent criteria, given that the municipality received negative scores in several areas for its failure to disclose the minimum required as set forth in related Brazilian legislation. The largest city in Staroscky et al.'s (2013) study, Chapecó, also displayed a similar performance rating, as it met the requirements of the initial criteria, only to experience a drop in performance later. The least-met requirements in the Joinville municipality were those related to organizational overview and its workforce, among which the only item that received a positive score was that which deals with public service exams (reaching the maximum score). Among the other items, there was a predominant lack of information. Among the last of the items concerning Joinville: response to users, update rate and historical data, the minimum of informational content, without any complementary information, was reported. The performance overview is useful for easier viewing of points that require attention for the improvement of the web portal's performance as a whole. Joinville, being the largest city in the sample (as well as the state), also earned the highest overall score at 29 points, which is shown 
in tables below.

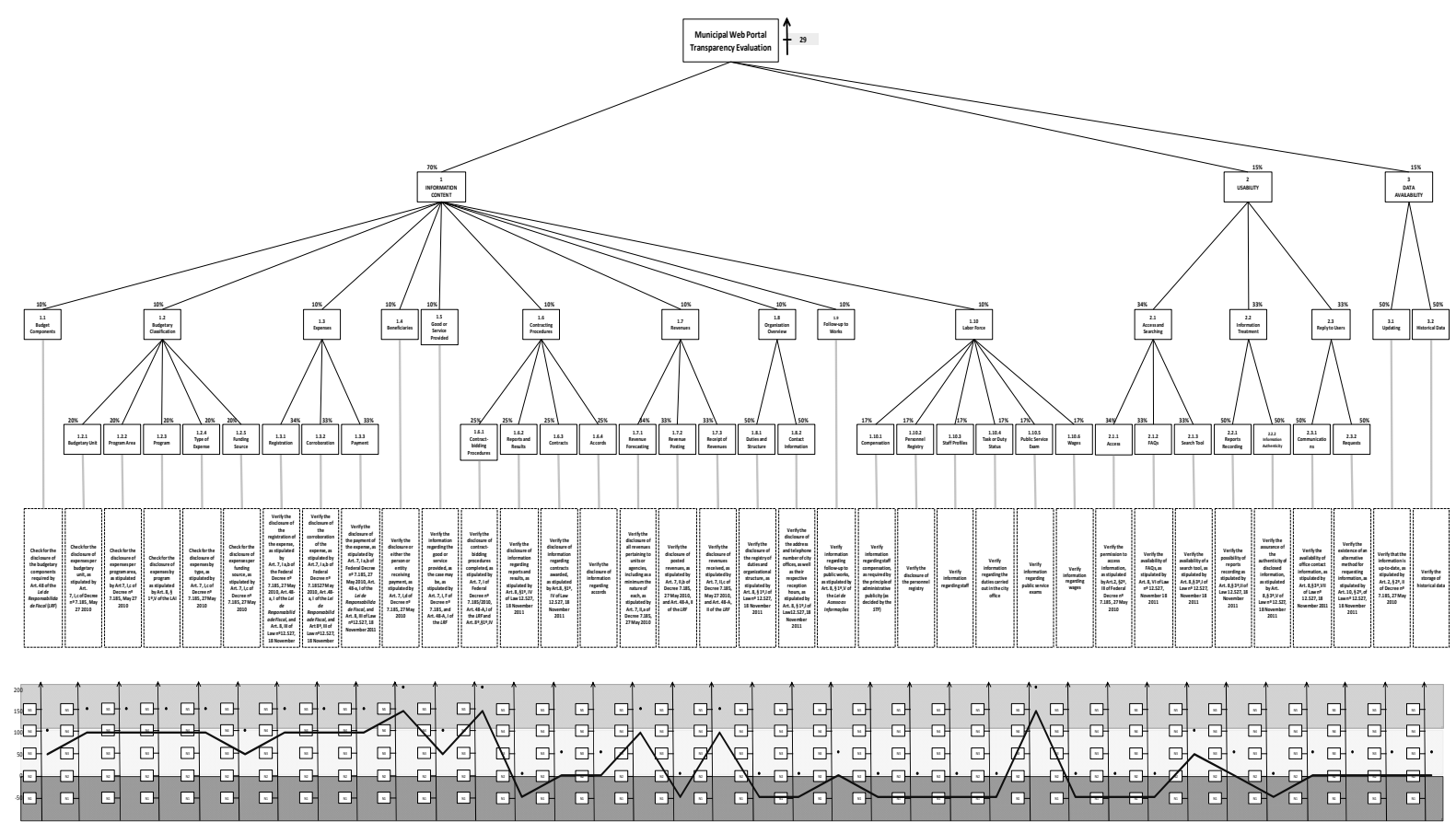

Figure 1. Performance profile of municipal web portals in the Joinville RDB

Source: Adapted from Nunes (2013).

From the outset, as per Table 2, contrary to the results of Staroscky et al. (2013), the standard deviation of the overall scores of the municipalities making up the Joinville RDB are shown to be low, at 14 points, ranging between -12 and 29 points. The average also increased to two points, increasing from -15 , as shown in the previous study on the Chapecó RDB. The highest-scoring municipalities were Joinville and Araquari with 29 and 14 points, respectively, while São Francisco do Sul and São João do Itaperiú also earned positive scores. Conversely, the municipalities Balneário Barra do Sul, Barra Velha, Itapoá and Garuva stood out in a negative light, showing that the two lowest-scoring municipalities use the ST2a system. 
Table 2. Information content scores - criteria 1.1-5

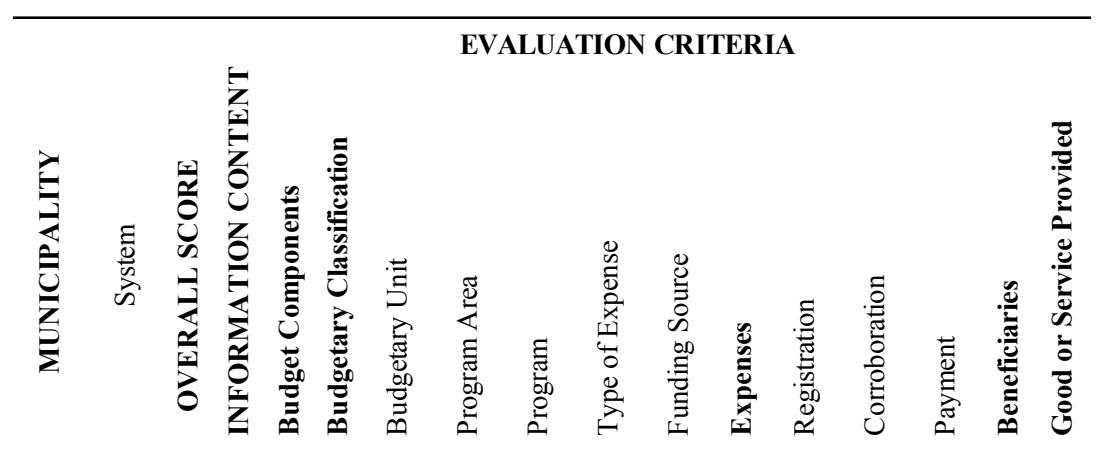

$\begin{array}{lllllllllllllllll}\text { 1. } & \mathbf{1 . 1} & \mathbf{1 . 2} & 1.2 .1 & 1.2 .2 & 1.2 .3 & 1.2 .4 & 1.2 .5 & \mathbf{1 . 3} & 1.3 .1 & 1.3 .2 & 1.3 .3 & \mathbf{1 . 4} & \mathbf{1 . 5}\end{array}$

\begin{tabular}{|c|c|c|c|c|c|c|c|c|c|c|c|c|c|c|c|c|}
\hline$\overline{A R Q}$ & ST1 & 14 & 27 & -50 & 80 & 100 & 100 & 100 & 100 & 0 & 50 & 50 & 50 & 50 & 150 & 50 \\
\hline BBS & ST2a & -12 & -23 & -50 & 10 & 150 & -50 & -50 & $\mathbf{5 0}$ & -50 & 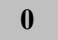 & 0 & 0 & 0 & 0 & -50 \\
\hline BRV & ST2a & -11 & -8 & $\mathbf{0}$ & 10 & 150 & -50 & -50 & $\mathbf{5 0}$ & -50 & 0 & 0 & 0 & 0 & 0 & $\mathbf{0}$ \\
\hline GRV & ST2 & -1 & -1 & -50 & 10 & 150 & -50 & -50 & $\mathbf{5 0}$ & -50 & 0 & 0 & 0 & 0 & 100 & $\mathbf{0}$ \\
\hline$\Gamma \mathbf{P}$ & ST2 & -9 & -2 & 0 & 10 & 150 & -50 & -50 & $\mathbf{5 0}$ & -50 & 0 & 0 & 0 & 0 & 100 & -50 \\
\hline JOI & ST1 & 29 & 45 & 50 & 90 & 100 & 100 & 100 & 100 & 50 & 100 & 100 & 100 & 100 & 150 & 50 \\
\hline SFS & ST2 & 3 & 14 & $\mathbf{0}$ & 20 & 150 & -50 & 0 & $\mathbf{5 0}$ & -50 & 0 & 0 & 0 & 0 & 100 & 50 \\
\hline SJI & ST3 & 1 & 3 & -50 & 30 & 150 & -50 & 50 & 50 & -50 & $\mathbf{0}$ & $\mathbf{0}$ & 0 & $\mathbf{0}$ & 100 & $\mathbf{0}$ \\
\hline \multicolumn{2}{|c|}{ MEAN } & 2 & 7 & -19 & 33 & 138 & -13 & 6 & 63 & -31 & 19 & 19 & 1 & 19 & 88 & 6 \\
\hline \multicolumn{2}{|c|}{ STD-DEV } & 14 & 21 & 37 & 33 & 23 & 69 & 68 & 23 & 37 & 37 & 37 & 37 & 37 & 58 & 42 \\
\hline \multicolumn{2}{|c|}{ MODE } & - & - & -50 & 10 & 150 & -50 & -50 & 50 & -50 & 0 & 0 & 0 & 0 & 100 & 50 \\
\hline
\end{tabular}

Source: Prepared by the authors, 2014.

In Tables 2 and 3, the results of the analysis of informational content are presented. Good results are shown up to and including criterion 1.5, with the standard deviation and average confirming this, and the greatest variations shown in the Program Area (69), program (68), and beneficiaries items, with 58 points. It is noteworthy that, in two of the criteria that showed the greatest variations, municipalities with excellent levels of information quality were identified. Demonstrating the contrast present in the Northern and Western municipalities of the state of Santa Catarina, Staroscky et al.'s (2013) study displayed variations as high as 100 points in one of the criteria. The "system" item was a major variable in the Araquari and Joinville municipalities as they exhibit reports with differing information regarding the following criteria: Program Area, program, and resources origins.

Now continuing with the presentation of the information content displayed in Tables 2 and 3, greater variations in the standard deviation are observed and it bears mentioning that at least one of the municipalities received a maximum score in the criteria showing the largest standard deviation, which were: contract-bidding procedures, with 94; public service exams, with 71, and proficiency and structure with 69 points. Poor scores were achieved in the criteria concerning on the accords, follow-up to works, and wages, for such information was communicated by a lone municipality. Not one of the web portals analyzed presented information regarding the release of revenues, and the majority of the municipal web portals do not display the minimum amount of contact information. Conversely, all of the municipalities present information on contracts, revenue forecasts, and revenue receipts. 
Table 3. Information content scores - criteria 1.6-10

\section{EVALUATION CRITERIA}

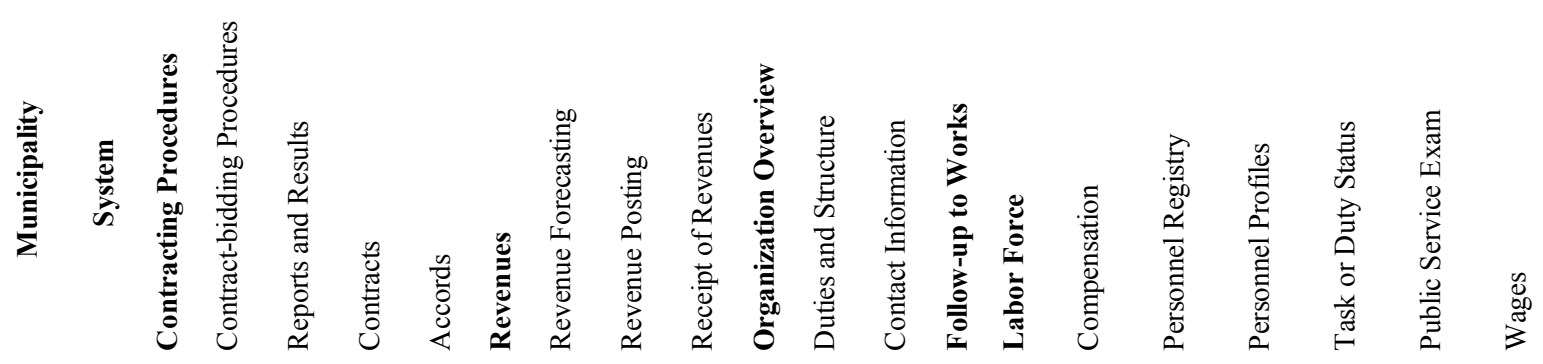

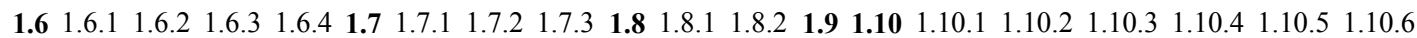

\begin{tabular}{|c|c|c|c|c|c|c|c|c|c|c|c|c|c|c|c|c|c|c|c|c|c|}
\hline ARQ & ST1 & -25 & 0 & -50 & 0 & -50 & 17 & 50 & -50 & 50 & 50 & 150 & -50 & -50 & 0 & -50 & 0 & 0 & -50 & 150 & -50 \\
\hline BBS & ST2a & -38 & -50 & -50 & 0 & -50 & 0 & 0 & -50 & 50 & -50 & -50 & -50 & -50 & 0 & 0 & 0 & 0 & 0 & -50 & $\mathbf{5 0}$ \\
\hline BRV & ST2a & -38 & -50 & -50 & 0 & -50 & 17 & 50 & -50 & 50 & -25 & 0 & -50 & -50 & 8 & 0 & 100 & 0 & 0 & 0 & -50 \\
\hline GRV & ST2 & 25 & 150 & 0 & 0 & -50 & 17 & 50 & -50 & 50 & -50 & -50 & -50 & -50 & -8 & 0 & 0 & 0 & -50 & 50 & -50 \\
\hline ITP & ST2 & -13 & -50 & 50 & 0 & -50 & 17 & 50 & -50 & 50 & -25 & -50 & 0 & -50 & -8 & 0 & 0 & 0 & 0 & 0 & -50 \\
\hline JOI & ST1 & 25 & 150 & -50 & 0 & 0 & 51 & 100 & -50 & 100 & -50 & -50 & -50 & 0 & -17 & -50 & -50 & -50 & -50 & 150 & -50 \\
\hline SFS & ST2 & 0 & 50 & 0 & 0 & -50 & 17 & 50 & -50 & 50 & 25 & 0 & 50 & -50 & -25 & 0 & -50 & -50 & -50 & 50 & -50 \\
\hline SJI & ST3 & 38 & 150 & 50 & 0 & -50 & 51 & 100 & -50 & 100 & -50 & -50 & -50 & -50 & -33 & -50 & -50 & -50 & -50 & 50 & -50 \\
\hline ME & CAN & -3 & 44 & -13 & $\mathbf{0}$ & -44 & 23 & 56 & -50 & 63 & -22 & -13 & -31 & -44 & -10 & -19 & -6 & -19 & -31 & 50 & -38 \\
\hline STD & -DEV & 30 & 94 & 44 & 0 & 18 & 18 & 32 & 0 & 23 & 39 & 69 & 37 & 18 & 14 & 26 & 50 & 26 & 26 & 71 & 35 \\
\hline MC & DDE & -38 & -50 & -50 & 0 & -50 & 17 & 50 & -50 & 50 & -50 & -50 & -50 & -50 & 0 & 0 & 0 & 0 & -50 & 50 & -50 \\
\hline
\end{tabular}

Source: Prepared by the authors, 2014.

In Staroscky et al.'s (2013) study on the Chapecó RDB, there was a congruency with the Joinville RDB in terms of the negative standouts, among which, the lack of the portal's corresponding city office's contact information is clear, given the ease with which the municipalities could make that information public. Another detail is that, while the Chapecó RDB municipalities' lack of information regarding its staff is incontrovertible, such information is repeatedly presented by the municipalities of the Joinville RDB.

The score-values of the two remaining areas of concern are shown in Table 4: usability and data availability. Apropos, the predominant adherence to related legislation bears mentioning, in concern to the following items: search tools, communication and updating of information in the system, seeing as how just two municipalities do not disclose related information in their respective web portals on the workday following its posting to their internal systems. The fact that the municipality of Balneário Barra do Sul has over six years of historical data available for viewing in its web portal calls the attention of the observer. Unfortunately, not one of the municipalities met with the requirements set by related legislation regarding the publication of FAQs, which serve to address common and recurring concerns on part of the citizens that access the municipal web portal. 
Table 4. Information usability and availability criteria scores - areas of concern No. 2 and 3

\section{EVALUATION CRITERIA}

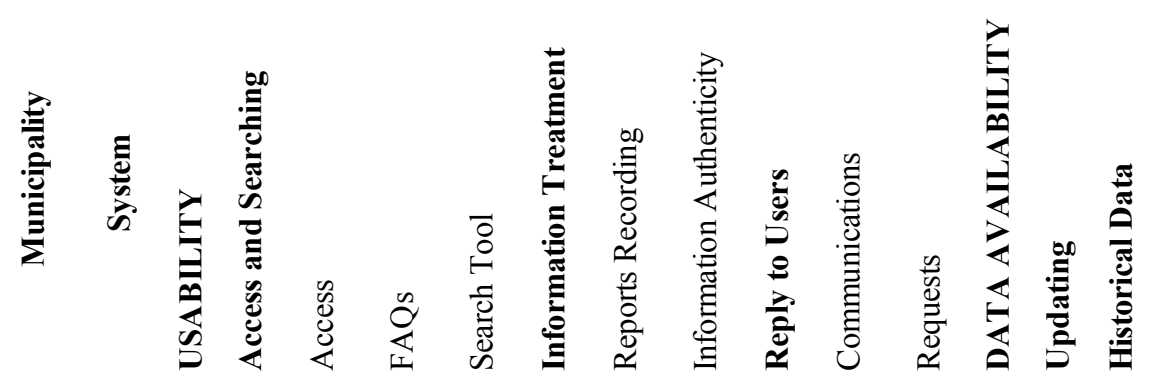

$\begin{array}{llllllllllllll}2 & \mathbf{2 , 1} & 2.1 .1 & 2.1 .2 & 2.1 .3 & \mathbf{2 , 2} & 2.2 .1 & 2.2 .2 & \mathbf{2 , 3} & 2.3 .1 & 2.3 .2 & \mathbf{3} & \mathbf{3 , 1} & \mathbf{3 , 2}\end{array}$

\begin{tabular}{|c|c|c|c|c|c|c|c|c|c|c|c|c|c|c|c|}
\hline ARQ & ST1 & -30 & -17 & $\mathbf{0}$ & -50 & 0 & -50 & -50 & -50 & -25 & $\mathbf{0}$ & -50 & $\mathbf{0}$ & 50 & -50 \\
\hline BBS & ST2a & -22 & -17 & 0 & -50 & 0 & -25 & -50 & 0 & -25 & 0 & -50 & 50 & -50 & 150 \\
\hline BRV & ST2a & -11 & -34 & -50 & -50 & 0 & 0 & 0 & 0 & 0 & 0 & 0 & -25 & -50 & 0 \\
\hline GRV & ST2 & -31 & -17 & -50 & -50 & 50 & -50 & -50 & -50 & -25 & $\mathbf{0}$ & -50 & 25 & 0 & 50 \\
\hline ITP & ST2 & -28 & -33 & 0 & -50 & -50 & -50 & -50 & -50 & 0 & $\mathbf{0}$ & 0 & -25 & 0 & -50 \\
\hline JOI & ST1 & -14 & -17 & -50 & -50 & 50 & -25 & 0 & -50 & 0 & 0 & 0 & 0 & 0 & 0 \\
\hline SFS & ST2 & -22 & -17 & 0 & -50 & 0 & -50 & -50 & -50 & 0 & 0 & 0 & -25 & 0 & -50 \\
\hline SJI & ST3 & -8 & 1 & 50 & -50 & 0 & -25 & 0 & -50 & 0 & 0 & 0 & 0 & 50 & -50 \\
\hline \multicolumn{2}{|c|}{ AVERAGE } & -21 & -19 & -13 & -50 & 6 & -34 & -31 & -38 & -9 & $\mathbf{0}$ & -19 & $\mathbf{0}$ & $\mathbf{0}$ & $\mathbf{0}$ \\
\hline \multicolumn{2}{|c|}{ STD. DEV. } & 9 & 11 & 35 & $\mathbf{0}$ & 32 & 19 & 26 & 23 & 13 & $\mathbf{0}$ & 26 & 27 & 38 & 71 \\
\hline \multicolumn{2}{|c|}{ MODE } & -22 & -17 & $\mathbf{0}$ & -50 & $\mathbf{0}$ & -50 & -50 & -50 & $\mathbf{0}$ & $\mathbf{0}$ & $\mathbf{0}$ & $\mathbf{0}$ & $\mathbf{0}$ & -50 \\
\hline
\end{tabular}

Source: Compiled by the authors, 2014.

Upon comparison to Staroscky et al.'s (2013) study on the Chapecó RDB, the credibility of the information present in the Balneário Barra do Sul and Barra Velha's web portals is suspect, given that none of the Chapecó RDB municipalities met this requirement. Nevertheless, three of the municipalities in the Joinville RDB analyzed presented hindrances to the access of certain information, which was different from the case of the Chapecó RDB in that none of the municipal web portals of the later required a user login for access to information.

\section{Closing Remarks}

A joint analysis of the results of this study and those obtained in Pires et al. (2013) reveals the possibility of observing a defined path towards high quality, efficient, and effective public transparency. Given that, in congruence with the methodologies employed here, municipalities including Novo Hamburgo -analyzed by the authors cited previously- and Joinville -included in the present study- show good transparency practices. Despite the initial comparability-related dilemma due to the differing methodologies used (the first, being more superficial in nature, while the present study was more in-depth, by comparison); Nunes (2013, pg. 101) presents a ranking of the municipalities with populations of more than 50,000 in the Southern region, in which Novo Hamburgo and Joinville rank 30th and 32nd, respectively, with corresponding scores of 30 and 29 points. As a coincidence, the municipality of Santa Maria ranks 27th on that same scale, tying with two other municipalities that also scored 31 points on the overall evaluation. As the model proposed by Nunes (2013) takes more items into consideration than those in the analysis in Pires et al. (2013), a further study might be necessary to detail a comparison of the two methodologies and identify the influence of potential biases.

Based on the analyses carried out in this study, it can be noted that a culture of transparency is still lacking at a fundamental level, given that overall evaluation revealed that half of the municipalities making up the sample received positive, while the other half, negative, scores. This indicates $50 \%$ of the municipalities in the sample do not disclose the minimum required by related Brazilian legislation. 
Returning to the research question, which is, "what is the level of transparency of the web portals of the municipalities making up the Regional Development Bureau - RDB - of Joinville, SC, in accordance with the related requirements stated in Brazilian legislation?", this study reaches its objective of verifying the level of transparency of the municipalities making up the Joinville RDB, showing the proficiencies and shortcomings of the web portals analyzed. As the average overall evaluation score was two points, on a scale of -50 to 150 possible points, it can be said that the level of transparency of the municipalities in question remains low. This study contributes for its identification of the items for which efforts must be made so that a higher level of transparency might be achieved.

Analyses also showed that a concern towards the release of more-detailed information regarding public accounts exists. Conversely, such as in some cases of contract-bidding processes and the documentation originating from such, the level of transparency due is not displayed, taking into account the fact that it is from these processes that the goods and services used by the municipality stem. Basic information, such as the activities of each branch or office, governmental structure, contact information, follow-up to works and FAQs are not yet made available to the public. It is important to mention that the level of transparency is highly influenced by the system used in the municipal web portal, and as such more practical and detailed systems should be encouraged, for the benefits of such help not only the municipality, but also the populace.

Comparison to the Chapecó RDB contributes to the development of transparency in the State of Santa Catarina in that it demonstrates the existing contrasts between the municipalities of the west and northern regions. Along these lines, upon comparison of this study with that of Staroscky et al. (2013), some contrasts can be identified. It stands to reason that there is a direct relationship between the economic potential and the level of transparency of each of the municipalities, based off the fact that those of the Joinville RDB show a higher level of transparency than those of the Chapecó RDB. According to the data provided by Staroscky et al. (2013), there are municipalities in the Chapecó RDB that do not even maintain a web portal, while, on the contrary, all of the Joinville RDB municipalities do publish one. Simultaneously, there were some municipalities in the Joinville RDB that presented hindrances to user access to information, which was not a weakness identified within the Chapecó RDB. The notion of a link between the economic potential and level of transparency of the municipalities analyzed presents an opportunity for further studies that might examine the factors that contribute to public-sector transparency.

Of the limitations on the present study, the following stand out: (I) the number of municipalities researched, given that only those making up the Joinville RDB were taken into consideration; (II) the difficulty present in data collection, due to the fact that the various municipalities use different transparency and accountability systems; and (III) the availability of data, whether as a result of the hindrances to the access of information or the poor functionality of the web portal servers, the latter of which required, in several cases, repeated attempts at searching.

In striving to widen the research on transparency in the state of Santa Catarina, it is suggested that future studies analyze the municipalities making up other RDBs, using the same evaluation model, so that a mapping of the transparency of municipalities in Santa Catarina might be constructed. This, reiterating the recommendations indicated in Nunes (2013), which proposes that the model employed here be applied to other Brazilian municipalities and states, if not other governmental institutions.

\section{References}

Bergue, S. T. (2011). Modelos de gestão em organizações públicas: teorias e tecnologias para análise e transformação organizacional. Caxias do Sul: Educs.

Bordignon, M., \& Minelli, E. (2001) Rules transparency and political accountability. Journal of Public Economics, 80(1), 73-98. http://dx.doi.org/10.1016/S0047-2727(00)00109-2

Brazil. (1988). Constituição da República Federativa do Brasil de 1988. Brasília: Senado Federal.

Brazil. Decreto $\mathrm{n}^{\circ} .7 .185$, de 27 de maio de 2010. Dispõe sobre o padrão mínimo de qualidade do sistema integrado de administração financeira e controle, no âmbito de cada ente da Federação, nos termos do art. 48, parágrafo único, inciso III, da Lei Complementar no 101, de 4 de maio de 2000, e dá outras providências.

Brazil. Lei Complementar $n^{\circ} 101$, de 4 de maio de 2000. Estabelece normas de finanças públicas voltadas para a responsabilidade na gestão fiscal e dá outras providências.

Brazil. Lei Complementar $\mathrm{n}^{\circ}$ 131, de 27 de maio de 2009. Acrescenta dispositivos à Lei Complementar No. 101, de 4 de maio de 2000, que estabelece normas de finanças públicas voltadas para a responsabilidade na 
gestão fiscal e dá outras providências, a fim de determinar a disponibilização, em tempo real, de informações pormenorizadas sobre a execução orçamentária e financeira da União, dos Estados, do Distrito Federal e dos Municípios.

Brazil. Lei $\mathrm{n}^{\circ}$. 12.527, de 18 de novembro de 2011. Regula o acesso a informações previsto no inciso XXXIII do art. 5o, no inciso II do $\S 3$ o do art. 37 e no $\S 2$ o do art. 216 da Constituição Federal; altera a Lei no 8.112, de 11 de dezembro de 1990; revoga a Lei no 11.111, de 5 de maio de 2005, e dispositivos da Lei no 8.159, de 8 de janeiro de 1991; e dá outras providências.

Controladoria-Geral da União (CGU). (2011). Acesso à informação pública: uma introdução à Lei ${ }^{\circ} 12.527$, de 18 de novembro de 2011. Brasília (DF).

Davis, J. (2004). Corruption in public service delivery: Experience from South Asia's water and sanitation sector. World Development, 32(1), 53-71. http://dx.doi.org/10.1016/j.worlddev.2003.07.003

Ensslin, L., Montibeller-Neto, G., \& Noronha, S. M. (2001). Apoio à decisão: metodologias para estruturação de problemas e avaliação multicritério de alternativas. Florianópolis: Insular.

FIESC. (2013). Santa Catarina em Dados. Florianópolis, v. 23, p. 1-176. Retrieved April 13, 2014, from http://www2.fiescnet.com.br/web/recursos/VUVSR016a3pPQT09

Gil, A. C. (2010). Como elaborar projetos de pesquisa (5th ed.). São Paulo: Atlas.

Grimmelikhuijsen, S., \& Klijn, A. (2015). The Effects of Judicial Transparency on Public Trust: Evidence from a Field Experiment. Public Administration, (1995), 1-17. http://dx.doi.org/10.1111/padm.12149

Hillebrandt, M. Z., Curtin, D., \& Meijer, A. (2014). Transparency in the EU Council of Ministers: An Institutional Analysis. European Law Journal, 20(1), 1-20. http://dx.doi.org/10.1111/eulj.12051

IBGE. (2014). IBGE Cidades: informações sobre municípios brasileiros. Retrieved February 7, 2014, from http://www.cidades.ibge.gov.br/xtras/uf.php?lang=\&coduf=42\&search=santa-catarina

Kierkegaard, S. (2009). Open access to public documents - More secrecy, less transparency! Computer Law and Security Review, 25(1), 3-27. http://dx.doi.org/10.1016/j.clsr.2008.12.001

Kissler, L., \& Heidemann, F. G. (2006) Governança pública: novo modelo regulatório para as relações entre Estado, mercado e sociedade? Revista de Administração Pública, 40(3), 479-499. http://dx.doi.org/10.1590/S0034-76122006000300008

Lyrio, M. V. L. (2008). Modelo para avaliação de desempenho das secretarias de desenvolvimento regional (SDR's) do Governo do Estado de Santa Catarina: a perspectiva da MCDA-C. $202 \mathrm{f}$. Thesis (Master of Accountancy). Graduate Program in Accounting. Universidade Federal de Santa Catarina, Florianópolis.

Lyrio, M. V. L., Brotti, V., Ensslin, L., \& Ensslin, S. R. (2008). Proposta de um modelo para avaliar o grau de transparência das demonstrações financeiras publicadas por uma Instituição Pública de Ensino Superior Brasileira: a abordagem da Metodologia Multicritério de Apoio à Decisão - Construtivista. Revista UNB Contábil, 11(1-2), 170-186.

MCivor, R., Mchugh, M., \& Cadden, C. (2002). Internet technologies: Supporting transparency in the public sector. International Journal of Public Sector Management, 15(3), 170-187. http://dx.doi.org/10.1108/09513550210423352

Nunes, G. S. F. (2013). Avaliação da transparência pública à luz da legislação brasileira: um estudo nos municípios da região sul do Brasil. pg 163. Thesis (Master of Accountancy). Graduate Program in Accounting. Universidade Federal de Santa Catarina, Florianópolis.

Olowu, B. (1999). Combatting corruption and economic crime in Africa An evaluation of the Botswana Directorate of Corruption and. International Journal of Public Sector Management, 12(7), 604-614. http://dx.doi.org/10.1108/09513559910306130

Pillay, S. (2004). Corruption - The challenge to good governance: A South African perspective. International Journal of Public Sector Management, 17(7), 586-605. http://dx.doi.org/10.1108/09513550410562266

Pires, A. M., Scherer, F. L., Santos, M. B., \& Carpes, A. M. (2013). Transparência da gestão pública municipal: um estudo nos municípios de Santa Maria e Novo Hamburgo / RS. Revista Estudos do CEPE, Santa Cruz do Sul, n38, pgs.131-160, jul./dec.

Riley, S. P. (1998). The political economy of anti-corruption strategies in Africa. European Journal of Development Research, 10(1), 129-159. http://dx.doi.org/10.1080/09578819808426705 
Ríos, A.-M., Bastida, F., \& Benito, B. (2014). Budget Transparency and Legislative Budgetary Oversight: An International Approach. The American Review of Public Administration, 1-23. http://dx.doi.org/10.1177/0275074014565020

Rossi, T., Murillo-Fort, C., \& Puente-Karolys, J. C. (2002). Transparencia en las adquisiciones del sector público: el caso de los hospitales de la Ciudad de Buenos Aires. Gaceta Sanitaria, 16(1), 94-104. http://dx.doi.org/10.1016/S0213-9111(02)71638-5

Roy, B. (1993). Decision science or decision-aid science? European Journal of Operational Research, 66(2), 184-203. http://dx.doi.org/10.1016/0377-2217(93)90312-B

Roy, B. (1994). On operational research and decision aid. European Journal of Operational Research, 73, 23-26. http://dx.doi.org/10.1016/0377-2217(94)90136-8

Roy, B., \& Vanderpooten, D. (1996). The European School of MCDA: Emergence, Basic Features and Current Works. Journal of multi-criteria decision analysis, $22-38$. http://dx.doi.org/10.1002/(SICI)1099-1360(199603)5:1<22::AID-MCDA93>3.3.CO;2-6

Secchi, L. (2009). Modelos organizacionais e reformas na administração pública. Revista de Administração Pública, 43(2), 347-369. http://dx.doi.org/10.1590/S0034-76122009000200004

Slomski, V. (2009). Controladoria e governança na gestão pública (1st ed.). 3. reimpr. São Paulo: Atlas.

Staroscky, E. A., Nunes, G. S. F., Lyrio, M. V. L., \& Lunkes, R. J. (2013). Transparência no setor público municipal: Uma análise dos portais municipais das prefeituras atendidas pela Secretaria de Desenvolvimento Regional de Chapecó (SC). In: XVI Congresso Internacional de Contabilidade $e$ Auditoria. A contabilidade como fator de transparência. Anais... Lisboa, v. 1, p. 156.

Tavares, L. E., \& Pereira, N. B. (2011). Transparência pública na era digital. In: V Simpósio Nacional ABCiber UDESC/UFSC. Anais... Florianópolis, Nov.

Zafarullah, H., \& Siddiquee, N. A. (2001). Dissecting Public Sector Corruption in Bangladesh: Issues and Problems of Control. Public Organization Review, 1(4), 465-486. http://dx.doi.org/10.1023/A:1013740000213

Zipparo, L. (1999). Encouraging Public Sector Employees to Report Workplace Corruption. Australian Journal of Public Administration, 58(2), 83-93. http://dx.doi.org/10.1111/1467-8500.00091

\section{Copyrights}

Copyright for this article is retained by the author(s), with first publication rights granted to the journal.

This is an open-access article distributed under the terms and conditions of the Creative Commons Attribution license (http://creativecommons.org/licenses/by/3.0/). 